\title{
TEKNOLOGI MENDUKUNG SISWA BELAJAR DALAM MATA PELAJARAN ILMU PENGETAHUAN SOSIAL TERINTEGRASI
}

\author{
Tri Nurza Rahmawati \\ Mahasiswa S3 Prodi Ilmu Pendidikan UNP \\ trinurzarahmawati@gmail.com
}

\begin{abstract}
Absract - This article provides an overview of strategies for using technology to support student learning in integrated Social Science subjects. The learning environment for Social Science subjects can focus on integrating and learning simultaneously for various levels of students. Social Science is a multidisciplinary science in solving problems. This study illustrates four strategies for using technology to support student learning in integrated Social Science among them; a) providing authentic learning contexts, b) offering webbased inquiry environments, c) extending learning through immersive and interactive technology, and d) turning students from recipients into creators. This article also discusses the challenges that are manifested in learning integrated learning environments. This study provides practical implications and research directions for technology-supported learning in an integrated learning environment learning environment. The use of technology in the four strategies identified supports student learning and enhances student experience in ways that are meaningful and support the ideas of students knowing and doing. The study chosen also shows strategies for using technology used to support student learning in different ways. Related Social Sciences Subjects; for example in the discipline of Sociology that examines the problem of poverty that can be discussed with anthropology or culture, geography or the environment and its history.
\end{abstract}

Keyword: Technology, Social Sciences, Integrated

\begin{abstract}
Abstrak- Artikel ini memberikan ulasan mengenai strategi penggunaan teknologi untuk mendukung pembelajaran siswa pada mata pelajaran Ilmu Pengatahuan Sosial yang terintegrasi. Lingkungan belajar mata pelajaran Ilmu Pengatahuan Sosial dapat fokus pada pengintegrasian dan pembelajaran secara bersamaan untuk berbagai tingkatan pelajar. Ilmu Pengatahuan Sosial merupakan Ilmu pengetahuan multidisiplin dalam memecahkan masalah. Studi ini menggambarkan empat strategi penggunaan teknologi untuk mendukung pembelajaran siswa dalam Ilmu Pengatahuan Sosial terintegrasi diantarnya; a) menyediakan konteks pembelajaran otentik, b) menawarkan web-lingkungan penyelidikan berbasis, c) memperluas pembelajaran melalui imersif dan teknologi interaktif, dan d) mengubah siswa dari penerima menjadi pencipta. Artikel ini juga membahas tantangan yang terwujud dalam pembelajaran lingkungan belajar terintegrasi. Studi ini memberikan implikasi praktis dan arahan penelitian untuk pembelajaran yang didukung teknologi dalam lingkungan belajar lingkungan belajar yang terintegrasi. Penggunaan teknologi dalam empat strategi yang diidentifikasi mendukung pembelajaran siswa dan meningkatkan pengalaman siswa dengan cara yang bermakna dan mendukung gagasan siswa mengetahui dan melakukan. Studi yang dipilih juga menunjukkan strategi penggunaan teknologi yang digunakan untuk mendukung pembelajaran siswa dengan cara yang berbeda. Subjek Ilmu Pengetahuan Sosial yang terkait; misalnya pada disiplin ilmu Sosiologi yang mengkaji masalah kemisikinan yang dapat dibahas dengan mata pelajaran antropologi atau budaya, geografi atau lingkungan serta sejarahnya.
\end{abstract}

Kata Kunci: Teknologi, Ilmu Pengetahuan Sosial, Terintegrasi 


\section{PENDAHULUAN}

Lingkungan belajar terintegrasi mengacu pada konteks belajar di mana siswa belajar lebih dari satu disiplin ilmu. Ilmu Pengetahuan Sosial adalah salah satu mata pelajaran yang terintegrasi yaitu terdiri dari mata pelajaran Geografi, Sejarah, Sosiologi Antropologi dan sebagainya. Serta praktik multi-disiplin pengetahuan dalam memecahkan suatu masalah. Lingkungan belajar Ilmu Pengetahuan Sosial yang terintegrasi dapat terjadi dalam pelajaran, unit, kursus, atau program melalui pemecahan masalah secara langsung. Siswa dapat menjadi lebih inovatif dan kreatif dengan dihadapkan pada lingkungan belajar interdisipliner seperti mata pembelajaran Ilmu Pengetahuan Sosial yang terintegrasi lingkungan. Namun, ada tantangan yang terkait dengan desain dan implementasi lingkungan seperti itu.

Pertama, batas-batas disiplin tradisional harus dipecah agar efektif masukkan banyak disiplin ke dalam pelajaran atau unit yang dirancang khusus. Kedua, keahlian guru mungkin tidak mencakup semua mata pelajaran Ilmu Pengetahuan Sosial dalam memfasilitasi siswa belajar dalam konteks pembelajaran yang terintegrasi. Terakhir, pembelajaran dalam lingkungan Ilmu Pengetahuan Sosial terintegrasi dapat dilakukan secara kognitif membebani siswa karena siswa harus belajar dan menerapkan pengetahuan konten berbagai mata pelajaran secara bersamaan dalam pemecahan masalah (Lamb, Akmal, \& Petrie, 2015).

Memfasilitasi jenis pembelajaran siswa ini bukan tugas yang mudah bagi guru dalam konteks pembelajaran seperti itu. Kemajuan teknologi pendidikan telah menyediakan berbagai peluang untuk mendukung pembelajaran siswa, dan mereka menawarkan harga yang unik untuk lingkungan belajar Ilmu Pengetahuan Sosial yang kompleks dan terintegrasi. Misalnya belajar pengalaman dapat diperluas menggunakan teknologi imersif dan interaktif (misalnya, simulasi dan game) memfasilitasi pembelajaran berbagai mata pelajaran secara bersamaan. Pemahaman siswa tentang isi pelajaran dapat ditingkatkan juga dengan penggunaan teknologi (US Department of Education, 2017). Makalah ini mengulas dan memberikan contoh praktis strategi penggunaan teknologi, seperti penggunaan penyelidikan berbasis web dan computer simulasi untuk mendukung pembelajaran siswa dalam lingkungan belajar Ilmu Pengetahuan Sosial yang terintegrasi. Penulis juga membahas tantangan yang terkait dalam lingkungan belajar yang terintegrasi.

Penerapan lingkungan belajar yang terintegrasi membantu memecah batasbatas pembelajaran disiplindan mendorong peserta didik untuk membuat koneksi antar disiplin ilmu (Drake, 2012). Misalnya, siswa belajar tentang konversi satuan dari meter ke kaki dalam konteks memecahkan masalah konstruksi teknik (Menghubungkan matematika dengan teknik). Penelitian menunjukkan bahwa pembelajaran Ilmu Pengetahuan Sosial terintegrasi mendorong keilmuan penyelidikan dan proses desain teknik (Kennedy \& Odell, 2014) dan meningkatkan teknologi dan ilmiah literasi (Breiner, Harkness, Johnson, \& Koehler, 2012). Namun, penelitian juga menunjukkan banyak guru yang tidak cukup siap untuk mengajar Ilmu Pengetahuan Sosial .cx`0063 (Epstein \&Miller, 2011). Akibatnya, pembelajaran siswa dapat dibatasi oleh pengetahuan konten guru tentang mata pelajaran 
diajarkan. Dalam lingkungan belajar Ilmu Pengetahuan Sosial yang terintegrasi, siswa harus memiliki pengetahuan tertentu (misalnya, tentang konsepkonsep dari ilmu geografi, sosiologi dan lain sebagainya) dan tahu bagaimana menerapkan pengetahuan itu untuk menyelesaikan masalah (Dewan Riset Nasional, 2015). Saling ketergantungan ini menambah kompleksitas dalam hal belajar dan memfasilitas belajar siswa dalam lingkungan belajar Ilmu Pengetahuan Sosial yang terintegrasi. Integrasi Ilmu Pengetahuan Sosial juga membutuhkan luas kolaborasi antara guru dan ahli materi pelajaran, yang dapat menciptakan tantangan tambahan karena sifat menuntut kolaborasi yang sukses (Gauvain, 2014).

Teknologi mengacu pada koleksi luas alat, modalitas pengiriman dan presentasi, serta strategi untuk memandu penggunaan teknologi (yaitu, strategi penggunaan teknologi) (Tamim, Bernard, Borokhovski, Abrami, \& Schmid, 2011). Teknologi dapat digunakan untuk meningkatkan keterlibatan dan motivasi siswa, memperluas pengalaman, dan mempercepat pembelajaran dengan bertindak sebagai sumber belajar tambahan baik di dalam maupun di luar kelas (AS Departemen Pendidikan, 2017). Selanjutnya, kemajuan teknologi juga berdampak pada pedagogi, seperti teori pembelajaran multimedia yang dikembangkan oleh Richard Mayer (Mayer, 2009), yang memandu desain dan aplikasi multimedia untuk keperluan pendidika. Teknologi juga dapat digunakan untuk mendukung kolaborasi dan komunikasi. Peserta didik dapat terlibat dalam asinkron dan komunikasi sinkron, bekerja dengan berbagai media, dalam kelompok atau individu, dan untuk berbagai hal tujuan (Mioduser, Nachmias,
\& Forkosh-Baruch, 2017). Kolaborasi yang didukung teknologi da komunikasi memfasilitasi pembelajaran aktif (Mioduser et al., 2017) dan dapat menyediakan forum untuk diskusi dan kegiatan menulis. Teknologi imersif dan interaktif, seperti augmented reality (AR) dan virtual reality (VR), dapat memberi siswa perasaan terbenam yang meningkatkan pemahaman dan keterlibatan siswa.

\section{METODE PENELITIAN}

Belum ada upaya sinergis dalam menghubungkan penggunaan teknologi dengan pembelajaran Ilmu Pengetahuan Sosial terintegrasi lingkungan dari perspektif menggunakan teknologi untuk mendukung pembelajaran siswa, penulis memilih untuk membahas pertanyaan penelitian dengan meninjau literatur empiris. Dimana teknik pengumpulan data dilakukan dengan menggunakan buku-buku, dan literature-literatur lainnya seperti jurnal ataupun artikel yang terkait dengan tema yang dibahas. Dengan cara mengutip pendapat-pendapat baik dari ahli mauapun dari peneliti lain yang terdapat di dalam sumber-sumber tersebut yang kemudian digunakan untuk memperkuat landasan teori yang digunakan.

Studi kepustakan ialah segala usaha yang dilakukan oleh peneliti untuk menghimpun informasi yang relevan dengan topik atau masalah yang akan atau sedang diteliti. Informasi itu dapat diperoleh dari buku-buku ilmiah, laporan penelitian, karangan-karangan ilmiah, tesis dan disertasi, peraturan-peraturan, ketetapan-ketetapan, buku tahunan, ensiklopedia dan sumber-sumber tertulis baik tercetak maupun elektronik lain (Setiawan, 2017). 


\begin{abstract}
Dengan melakukan studi kepustakaan, peneliti dapat memanfaatkan semua informasi dan pemikiran-pemikiran yang relevan dengan penelitiannya. Untuk melakukan studi kepustakaan, perpustakaan merupakan suatu tempat yang tepat guna memperoleh bahan-bahan dan informasi yang relevan untuk dikumpulkan, dibaca dan dikaji, dicatat dan dimanfaatkan.
\end{abstract}

\section{PEMBAHASAN}

\section{Menghubungkan Teknologi dengan Lingkungan Belajar Ilmu Pengetahuan Sosial Terintegrasi}

Teknologi menawarkan berbagai peluang bagi siswa untuk mempelajari teknologi dan alat dan terlibat konten subjek. Teknologi dapat memfasilitasi eksplorasi mata pelajaran Ilmu Pengetahuan Sosial dan memberikan dukungan bagi siswa sambungkan ide-ide disiplin yang berbeda, misalnya, ketika menggunakan simulasi. Teknologi juga mendorong siswa untuk mengatur kembali ide-ide ilmiah dan matematika dengan cara baru (misalnya, membangun robot atau membuat konten). Siswa dan guru mampu menciptakan dan memecahkan sejumlah besar masalah melalui penggunaan teknologi (Beal \& Cohen, 2012). Karena itu, sangat penting untuk menghubungkan teknologi dengan pembelajaran Ilmu Pengetahuan Sosial terintegrasi dan menyelidiki caranya untuk menggunakan teknologi untuk mendukung pembelajaran siswa dan mengatasi tantangan yang terkait dengan pembelajaran yang kompleks. Penggunaan teknologi dan konten subjek saling mempengaruhi satu sama lain (Koehler \& Mishra, 2009). Di sebuah lingkungan belajar Ilmu Pengetahuan Sosial yang didukung teknologi dan terintegrasi, teknologi, pembelajaran konten, dan professional pelatihan karier sering kali menjadi saling terkait dan tak terpisahkan. Dalam tulisan ini, komponen teknologi pada Ilmu Pengetahuan Sosial mengacu pada alat dan modalitas pengiriman (misalnya, menggunakan teks dan multimedia) (Tamim et al., 2011) yang membantu siswa menjadi pembelajar, pengguna, dan konsumen yang mahir secara teknologi, serta menjadi yang teknis, pelatihan disiplin terkait dengan kebutuhan industri dan persiapan tenaga kerja. Lingkungan belajar Ilmu Pengetahuan Sosial yang terintegrasi menuntut praktik-praktik inovatif seperti kolaborasi guru dan ahli materi pelajaran bekerja sama dengan siswa untuk memecahkan masalah dunia nyata (Nag, Katz, \& Saenz-Otero, 2013).

Implementasi lingkungan belajar Ilmu Pengetahuan Sosial yang terintegrasi dan inovasi terkaitnya praktik dapat difasilitasi melalui penggunaan teknologi yang efektif. Saat belajar Ilmu Pengetahuan Sosial, siswa tidak secara inheren mempelajari konsep Ilmu Pengetahuan Sosial dari struktur bangunan atau dari kegiatan desain (Chiu et al., 2013). Selama kegiatan bangunan atau desain ini, siswa dapat fokus pada kegiatan langsung "tanpa membuat koneksi untuk konsep Ilmu Pengetahuan Sosial yang mendasarinya "(Chiu et al., 2013, hal. 144). Namun, dengan janji Ilmu Pengetahuan Sosial terintegrasi lingkungan belajar dan pembelajaran yang didukung teknologi menjadi tantangan dengan pembelajaran Ilmu Pengetahuan Sosial. Itu perlu untuk menyelidiki bagaimana menggunakan teknologi untuk mendukung pembelajaran siswa di lingkungan Ilmu Pengetahuan Sosial terintegrasi. Sejak penggunaan teknologi harus spesifik konten (seperti 
yang dibahas dalam kerangka kerja TPACK) (Koehler \& Mishra, 2009), pengenalan teknologi ke dalam lingkungan pembelajaran menambah kompleksitas baru. Penulis berdiskusi di sini strategi penggunaan teknologi dalam mendukung pembelajaran siswa dalam lingkungan belajar Ilmu Pengetahuan Sosial yang terintegrasi dengan contoh spesifik terkait konten (studi).

Para penulis melakukan pencarian di EdITLib (Perpustakaan Digital Pendidikan dan Teknologi Informasi), Pendidikan Penelitian Lengkap (EBSCO), Pusat Informasi Sumber Daya Pendidikan (ERIC), Web of Science, dan Basis data Google Cendekia tentang studi terkait tentang penggunaan teknologi dan pembelajaran Ilmu Pengetahuan Sosial terintegrasi lingkungan. Kata kunci pencarian Ilmu Pengetahuan Sosial dan teknologi terintegrasi, kurikulum Ilmu Pengetahuan Sosial terintegrasi, Ilmu Pengetahuan Sosial terintegrasi dan pembelajaran yang didukung teknologi, dan lingkungan belajar Ilmu Pengetahuan Sosial terintegrasi. Penulis mencari literatur di mana teknologi digunakan untuk mendukung pembelajaran siswa dalam K20 terintegrasi (TK ke kuliah) lingkungan belajar Ilmu Pengetahuan Sosial. Kriteria inklusi adalah lingkungan belajar terintegrasi dan Kriteria eksklusi adalah lingkungan yang tidak terintegrasi. Pencarian terbatas pada studi yang diterbitkan pada tahun 2000 atau kemudian dalam jurnal peer-review untuk mencerminkan

kemajuan teknologi. Meskipun ada lebih dari 400 studi tentang pembelajaran yang didukung teknologi untuk masing-masing mata pelajaran, hanya beberapa studi yang dilakukan secara terpadu Lingkungan belajar Ilmu Pengetahuan
Sosial. Prosedur pengkodean terbuka adalah prosedur kualitatif yang banyak digunakan untuk menganalisis data berbasis teks, dalam hal ini, beberapa studi yang dipilih. Berikut ada empat strategi yang muncul dari analisis:

\section{Strategi Penggunaan Teknologi untuk Lingkungan Pembelajaran Ilmu Pengetahuan Sosial Terintegrasi Memberikan Konteks Belajar Otentik}

Pembelajaran otentik adalah pendekatan instruksional yang memberikan siswa kesempatan untuk menerapkan pengetahuan ke dunia nyata. masalah dunia, mempromosikan pemahaman yang lebih dalam bagi siswa (Kelley \& Knowles, 2016), yang khususnya relevan untuk lingkungan belajar Ilmu Pengetahuan Sosial yang terintegrasi. Subjek Ilmu Pengetahuan Sosial membutuhkan kesabaran dan ketekunan untuk menjadi dikuasai, yang merupakan sifat sulit untuk dipelihara pada siswa yang terbiasa dengan kepuasan instan (Demski, 2009). Konteks pembelajaran otentik penting untuk melibatkan peserta didik dan menunjukkan kepada mereka bagaimana mereka dapat menerapkannya belajar dalam kehidupan sehari-hari mereka. Ini dapat membantu menghasilkan rasa kepuasan belajar. Selanjutnya yang otentik konteks memberikan siswa dengan pengalaman langsung dalam memecahkan masalah dunia nyata dengan menggunakan kegiatan dan alat serupa sifatnya dengan para profesional. Konteks otentik juga membantu mempersiapkan siswa untuk karier teknis yang juga dapat memberdayakan dan memotivasi mereka (Kelley \& Knowles, 2016).

Pemodelan memungkinkan para ilmuwan untuk "mensimulasikan bagaimana komponen-komponen suatu 
Ilmu pengetahuan sosial bekerja bersama dan berinteraksi dengan masing-masing komponen lainnya "(Wu, 2010, hal. 197). Dalam studi Wu, siswa menggunakan APoMT untuk merencanakan, mengidentifikasi dan menghubungkan variabel, dan desain dan model uji (yaitu, kegiatan pemodelan). Para siswa belajar teknologi (proses pemodelan) dan pengetahuan ilmiah saat menggunakan APoMT, menyoroti manfaat mengintegrasikan disiplin Para penulis melakukan pencarian di EdITLib (Perpustakaan Digital Pendidikan dan Teknologi Informasi), Pendidikan Penelitian Lengkap (EBSCO), Pusat Informasi Sumber Daya Pendidikan (ERIC), Web of Science, dan Basis data Google Cendekia tentang studi terkait tentang penggunaan teknologi dan pembelajaran Ilmu Pengetahuan Sosial terintegrasi lingkungan. Kata kunci pencarian Ilmu Pengetahuan Sosial dan teknologi terintegrasi, kurikulum Ilmu Pengetahuan Sosial terintegrasi, Ilmu Pengetahuan Sosial terintegrasi dan pembelajaran yang didukung teknologi, dan lingkungan belajar Ilmu Pengetahuan Sosial terintegrasi. Penulis mencari literatur di mana teknologi digunakan untuk mendukung pembelajaran siswa dalam K20 terintegrasi (TK ke kuliah) lingkungan belajar Ilmu Pengetahuan Sosial. Kriteria inklusi adalah lingkungan belajar terintegrasi dan Kriteria eksklusi adalah lingkungan yang tidak terintegrasi. Pencarian terbatas pada studi yang diterbitkan pada tahun 2000 atau kemudian dalam jurnal peer-review untuk mencerminkan kemajuan teknologi. Meskipun ada lebih dari 400 studi tentang pembelajaran yang didukung teknologi untuk masing-masing mata pelajaran, hanya beberapa studi yang dilakukan secara terpadu Lingkungan belajar Ilmu Pengetahuan Sosial. Prosedur pengkodean terbuka adalah prosedur kualitatif yang banyak digunakan untuk menganalisis data berbasis teks, dalam hal ini, beberapa studi yang dipilih. Berikut ada empat strategi yang muncul dari analisis:

\section{Menawarkan Lingkungan \\ Penyelidikan Berbasis Web}

Pembelajaran berbasis inkuiri melibatkan membuat prediksi, menyelidiki, mengevaluasi, dan mengembangkan penjelasan (SpektorLevy, Israel, Plutov, \& Perry, 2017). Platform berbasis web dapat digunakan untuk mendukung permintaan siswa dan menyediakan sarana untuk penyelidikan praktik dan penjelasan fenomena sambil mengembangkan pemahaman tentang masalah ilmiah (National Research Council, 2015). Chiu dan Linn (2011) menggunakan penyelidikan sains berbasis lingkungan web (WISE) untuk mendukung integrasi teknik ke dalam sains sekunder dan kurikulum matematika memungkinkan siswa untuk melakukan penyelidikan ilmiah. Dalam modul WISE, siswa didorong untuk berpikir seperti insinyur, dan menerapkan konsep matematika dan fisika saat melakukan eksperimen. Satu unit kurikuler di WISE, para siswa dipandu melalui penyelidikan tentang keselamatan airbag dalam tabrakan mobil. Di unit lain tentang perubahan iklim, teknologi digunakan untuk membantu siswa memvisualisasikan efek rumah kaca dan melihat molekul simulasi. Siswa menggunakan sesi brainstorming online dan forum diskusi untuk berkolaborasi dengan rekan-rekan mereka dalam WISE. Siswa dapat melihat video yang relevan dalam WISE, dan 
kemudian memperbaiki atau menambahkan informasi ke mereka posting diskusi. Para siswa menikmati belajar dan menggunakan teknologi.

Lingkungan penyelidikan berbasis web memberikan kesempatan kepada siswa "untuk membandingkan, membedakan, mengkritik, dan membedakan "ide-ide yang ada dengan ide-ide baru (Chiu \& Linn, 2011, hal. 3). Di WISE siswa belajar tentang kekuatan, gerak, dan kecepatan dalam konteks mengemudi mobil. Ini membantu siswa mengidentifikasi dan memecahkan masalah secara realistis konteks melalui proses memunculkan ide (mengenali ide dan menghubungkan ide yang ada dan yang baru),menambah ide baru, membedakan ide, dan memilah ide. SiIlmu pengetahuan sosial generik dipecah menjadi lebih kecil bagian atau proses individu untuk membimbing siswa untuk menyelidiki hubungan antara variabel yang berbeda.

Dalam lingkungan penyelidikan berbasis web seperti WISE, siswa dapat belajar dan berkomunikasi dengan cara yang berbeda modalitas melalui multimedia dan berbagai alat komunikasi. Terjadinya penyelidikan berbasis web lingkungan membantu meringankan beberapa tantangan yang terkait dengan lingkungan belajar Ilmu Pengetahuan Sosial yang terintegrasi. Sebuah web lingkungan penyelidikan berbasis memungkinkan siswa untuk dengan mudah menggunakan tangkapan layar, berbagi catatan, dan gagasan kritik, semuanya yang memberikan dukungan bagi siswa untuk membangun ilmu pengetahuan dan teknik. Selain itu, tertanam penilaian, seperti yang ada dalam WISE, membantu mengukur koneksi siswa untuk konten sains dan keterampilan teknik, memfasilitasi integrasi pengetahuan konten subjek yang berbeda. Platform penyelidikan berbasis web secara eksplisit dapat membantu siswa mengembangkan pemahaman konten (misalnya, geografi) sambil mendukung siswa untuk membuat koneksi dengan mata pelajaran lain seperti sejarah dan sosiologi.

\section{Memperluas Pembelajaran dengan Teknologi Imersif dan Interaktif}

Teknologi imersif dan interaktif (mis., Simulasi, permainan) memberikan kesempatan bagi siswa untuk melakukannya melakukan eksperimen atau menyelidiki fenomena di luar kendala fisik (de Jong, Sotiriou, \& Gillet, 2014; Webb, Yang, \& Senocak, 2014). Misalnya, simulasi memungkinkan siswa untuk memanipulasi data, mengeksplorasi variabel, dan mengamati efeknya untuk mendapatkan pemahaman tentang hubungan antar variabel (de Jong, Linn, \& Zacharia, 2013). Teknologi inovatif, seperti AR dan VR, dapat memberikan pengalaman pembelajaran kontekstual (Dede et Al., 2015) dan menawarkan pengalaman mendalam, yang telah ditemukan untuk menambah nilai pembelajaran (Hsu et al., 2017; Restivo et al., 2014).

Teknologi imersif, seperti simulasi komputer, memberikan pendekatan unik untuk menjelaskan sulit dan kompleks proses dan fenomena baik di tingkat makro dan mikro (Webb et al., 2014; Yang et al., 2012). Dengan bantuan simulasi komputer, siswa dapat memanipulasi molekul, mengubah variabel yang berbeda, dan "melihat" fenomena yang tidak dapat diamati dengan mata telanjang. Penggunaan teknologi imersif dan interaktif, seperti simulasi komputer, sangat memudahkan 
siswa mempelajari berbagai materi pelajaran secara bersamaan dan membantu mengatasi batas-batas disiplin tunggal. Dalam studi Lamb dan Annetta, siswa dapat menggunakan virtual manipulatif (jenis lain dari teknologi immersive / simulasi) dengan berbagai metode dukungan dari grafik dan teks, ke gambar dan interaksi. Simulasi memberikan integrasi cairan ilmu pengetahuan dan teknologi, yang sebaliknya memberikan siswa cara yang lebih realistis untuk belajar. Dengan kemampuan untuk memanipulasi informasi tentang komputer, siswa memahami konsep kimia lebih baik.

\section{Membuat Konten}

Ketika mentransformasikan dari konten subjek, konsumen menjadi pembuat seperti membangun robot dengan kabel dan resistor dan kemudian pemrograman itu (Grubbs, 2013), siswa memperdalam pemahaman mereka tentang mata pelajaran Ilmu Pengetahuan Sosial, seperti serta kemampuan mereka untuk memecahkan masalah, memverifikasi solusi, dan berkolaborasi dengan orang lain. Menyediakan teknologi kanvas atau alat untuk memotivasi dan melibatkan peserta didik (misalnya, anak-anak pemrograman dengan Scratch atau bangunan Robot lego) dalam berbagai jenis pembuatan konten (Schradie, 2011). Membuat konten dengan penawaran teknologi pelajar berkesempatan untuk memamerkan proyek Ilmu Pengetahuan Sosial terintegrasi dan memberikan kesempatan untuk bermain peran dan terlibat tantangan desain (Grubbs, 2013). Pembuatan konten menggunakan teknologi mendukung keterampilan belajar yang menghubungkan siswa untuk karir masa depan (Cira et al., 2015) dan mengembangkan pemikiran kreatif dan keterampilan memecahkan masalah. Teknologi bias juga membantu siswa menyebarluaskan pembuatan konten mereka (misalnya, pameran online kota energi hijau) ke yang lebih besar audiens, sehingga mempromosikan lebih banyak kesempatan bagi siswa untuk memamerkan pembelajaran mereka dan memotivasi mereka menjadi pembuat konten sambil meningkatkan kemanjuran diri mereka dalam belajar. Ardito et al. (2014) mengilustrasikan bagaimana teknologi digunakan untuk mendukung siswa untuk menjadi pembuat konten dalam suatu lingkungan belajar Ilmu Pengetahuan Sosial terintegrasi yang berfokus pada geografi, sejarah, sosiologi, antropologi dan lain sebagainya.

Membuat konten dengan dukungan teknologi, seperti robot merancang dan pemrograman, mendukung aktif belajar dan pemahaman yang lebih dalam. Dengan membuat konten, siswa mengatur ulang dan membentuk kembali pengetahuan mereka, yang memperdalam pembelajaran mereka dan mendorong kreativitas. Dalam studi Ardito et al., Siswa berkembang dari belajar bagaimana memprogram untuk memanfaatkan konsep spesifik (misalnya, pernyataan kondisional, blok berulang) untuk robot pemrograman. Siswa menunjukkan pemikiran kolaboratif dalam desain, konstruksi, dan pemecahan masalah.

\section{KESIMPULAN}

Makalah ini memberikan ikhtisar strategi penggunaan teknologi untuk mendukung pembelajaran siswa secara terintegrasi lingkungan belajar Ilmu Pengetahuan Sosial. Penulis berharap dapat meningkatkan kesadaran akan persimpangan yang didukung teknologi 
pembelajaran dan pembelajaran Ilmu Pengetahuan Sosial terintegrasi. Saat ini, baik lingkungan belajar Ilmu Pengetahuan Sosial terintegrasi maupun teknologi telah sepenuhnya dimanfaatkan secara maksimal (Chiu et al., 2013). Keterbatasan penelitian saat ini tersedia mengenai strategi penggunaan teknologi dan lingkungan belajar Ilmu Pengetahuan Sosial terintegrasi menunjukkan lebih lanjut bahwa menghubungkan keduanya perlu dan kritis. Penggunaan teknologi dalam lingkungan belajar Ilmu Pengetahuan Sosial yang terintegrasi dapat memperluas pengajaran dan pembelajaran yang efektif melampaui apa yang mungkin dengan pendekatan belajar mengajar tradisional. Mengategorikan penggunaan teknologi strategi (misalnya, menyediakan konteks otentik, menawarkan lingkungan penyelidikan berbasis web, menggunakan interaktif dan teknologi immersive, dan membuat konten) dapat membantu pendidik mengadopsi strategi yang efektif untuk

\section{DAFTAR PUSTAKA}

Chiu, J. L. \& Linn, M. C. (2011). Knowledge integration and wise engineering. Journal of PreCollege Engineering Education Research, 1(1), 1-14.

Drake, S. M. (2012). Creating standards-based integrated curriculum: The common core state standards edition. Thousand Oaks, CA: Corwin Press. mendukung dan membimbing belajar siswa di lingkungan Ilmu Pengetahuan Sosial terintegrasi.

Penggunaan teknologi dalam empat strategi yang diidentifikasi dalam makalah ini keduanya mendukung pembelajaran siswa dan meningkatkan pengalaman siswa dengan cara yang bermakna dan mendukung gagasan siswa mengetahui dan melakukan, sebagai diadvokasi oleh inisiatif luas dalam pendidikan Ilmu Pengetahuan Sosial (Kanada 2067; Departemen Pendidikan AS, 2016). Studi yang dipilih juga menunjukkan strategi penggunaan teknologi yang digunakan untuk mendukung pembelajaran siswa dengan cara yang berbeda. Di dunia nyata subjek Ilmu Pengetahuan Sosial secara intrinsik terkait; misalnya, Sosiologi yang mengkaji masalah kemisikinan yang dapat dibahas dengan mata pelajaran antropologi atau budaya, geografi atau lingkungan serta sejarahnya.

Habash, R. W., \& Suurtamm, C. (2010). Engaging high school and engineering students: A multifaceted outreach program based on a mechatronics platform. IEEE transactions on education, 53(1), 136-143.

Lamb, R. L., \& Annetta, L. (2013). The use of online modules and the effect on student outcomes in a high school chemistry class. Journal of Science Education and Technology, 22(5), 603-613. 
Lunce, L. M. (2006). Simulations, bringing the benefits of situated learning to the traditional classroom. Journal of Applied Educational Technology 3(1), 3745.

Schradie, J. (2011). The digital production gap: The digital divide and Web 2.0 collide. Poetics, 39(2), 145-168. Smith, B., \& Mader, J. (2017). Align your curriculum with the ISTE standards. The Science Teacher 84 (5), 8.

Strauss, A., \& Corbin, J. M. (1990). Basics of qualitative research: Grounded theory procedures and techniques. Thousand Oaks, CA, US: Sage Publications, Inc.

Tamim, R. M., Bernard, R. M., Borokhovski, E., Abrami, P. C., \& Schmid, R. F. (2011). What forty years of research says about the impact of technology on learning: A second-order meta-analysis and validation study. Review of Educational Research, 81(1), 4-28.

U.S. Department of Education. (2017). Use of technology in teaching and learning. Retrieved from https://www.ed.gov/oii-news/usetechnology-teaching-and-learning. Webb, J., Yang, D., \& Senocak, I. (2014). Interactive molecular-level descriptions in engineering educational simulations. Proceedings of 2014 American Society for Engineering Education Annual Conference and Exposition (ASEE), Indianapolis, IN.

Yang, D., Streveler, R. A., Miller, R. L., Slotta, J., Matusovich, H., \& Magana, A. (2012). Using computer- based online learning modules to promote conceptual change: Helping students understand difficult concepts in thermal and transport science. International Journal of Engineering Education, 28(3), 686- 700. 